\title{
Protein II* Influences Ferrichrome-iron Transport in Escherichia coli $\mathrm{K} 12$
}

\author{
By J. W. COULTON AND V. BRAUN \\ Lehrstuhl Mikrobiologie II, Universität Tübingen, Auf der Morgenstelle 28, \\ D-7400 Tübingen, West Germany
}

(Received 17 May 1978; revised 7 August 1978)

\begin{abstract}
Ferrichrome-promoted iron uptake in Escherichia coli $\mathrm{K} 12$ is strictly dependent upon the ton $A$ gene product, a 'minor' outer membrane protein. By selection for mutants of $E$. coli resistant to phages which require 'major' outer membrane proteins as receptors, strains with pronounced protein deficiencies were constructed. Such strains were tested for anomalous behaviour of ferrichrome transport. No significant differences in iron uptake were detected in $E$. coli $\mathrm{K} 12$ strains with markedly reduced amounts of protein I. However, a reduction in the initial velocity (up to $40 \%$ ) was observed in $E$. coli deficient in outer membrane protein $\mathrm{II}^{*}$. This difference was only evident when cells were grown under iron-starvation conditions; it was abolished when cells were grown in rich medium. Kinetic parameters for ferrichrome transport were determined for maximum velocity but not for $K_{\mathrm{m}}$; double reciprocal plots showed a biphasic nature, probably attributable to a limited number of outer membrane binding sites and to the multi-component nature of the ferrichrome-iron transport system.
\end{abstract}

\section{INTRODUCTION}

The outer membrane of Escherichia coli contains several protein receptors which play a role in high-affinity uptake of certain substrates (Braun \& Hantke, 1977). These multicomponent transport systems include the $f e u B$ gene product for ferric-enterochelin uptake (Hantke \& Braun, 1975b), probably the cit protein for citrate-iron uptake (Hancock et al., 1976) and the ton $A$ specified protein which is the receptor for the ferrichrome complex (Hantke \& Braun, 1975a; Luckey et al., 1975). Some of these proteins have also been characterized as receptors for phages and colicins: for example, the tonA-coded protein of molecular weight 78000 is known to be the receptor for phages T1, T5 and $\phi 80$, and for colicin M. For all of the above-mentioned transport activities, except T5 infection, a functional $\operatorname{ton} B$ locus is also required. The gene product of $\operatorname{ton} B$ is so far unidentified.

In addition to these specific receptors for the translocation of solutes across the $E$. coli envelope, the outer membrane also contains major proteins which seem to be less specific in activity. Protein I ( 36000 daltons) is considered to be arranged as a pore-forming channel, permitting passage of hydrophilic substrates up to an exclusion limit of about 600 daltons (Nakae \& Nikaido, 1975). The role of protein II* (33000 daltons) is less clear. It requires lipopolysaccharide to act as inactivator of phage, and its positional specificity in the outer membrane may be directed by lipopolysaccharide (Schweizer et al., 1978). Some evidence implicates protein $\mathrm{II}^{*}$ in amino acid uptake (Manning et al., 1977) and in conjugation (Schweizer \& Henning, 1977). Both these major proteins show heterogeneity on polyacrylamide gels following electrophoresis. Proteins I and II* serve as phage receptors, in parallel to the situation described for proteins of specific transport systems.

The extent to which these proteins interact is of considerable interest in elucidating the 
architecture of the outer membrane. Cross-linking reagents have demonstrated extensive protein-protein interactions (Haller \& Henning, 1974), and through judicious use of bifunctional reagents which may be cleaved by reduction, specific interactions have been identified (Reithmeieı \& Bragg, 1977; Palva \& Randall, 1978). Protein I was cross-linked to dimers and trimers, and may be restricted to patches or channels formed in vivo by aggregation. Protein II* $^{*}$ was readily cross-linked to other II* molecules, suggesting their close proximity. Such nearest neighbour analyses, however, do not test the functional interplay of protein molecules. We have attempted to probe this by studying ferrichromepromoted iron uptake in mutants lacking major outer membrane proteins.

\section{METHODS}

Bacteriological methods. Table 1 lists the strains used. Bacteria were grown either in rich TY medium, composed of Difco tryptone $\left(8 \mathrm{~g} \mathrm{l}^{-1}\right)$, yeast extract $\left(5 \mathrm{~g} \mathrm{l}^{-1}\right)$ and sodium chloride $\left(5 \mathrm{~g}^{-1}\right)$, or in minimal medium of M9 salts (Adams, 1959) plus required growth supplements. To provide a sufficient source of iron, $1.0 \mathrm{~mm}$-citrate as chelator was added to M9 medium. Extraction of M9 salts by passage over Chelex-100 reduced iron concentrations to below those necessary for growth, and hence $0 \cdot 1 \mu \mathrm{M}-\mathrm{FeCl}_{3}$ was added to this 'low-iron' medium.

Uptake of radioactively labelled iron from ferrichrome. Bacteria grown overnight in TY medium at $37^{\circ} \mathrm{C}$ in a rotary shaking water bath were resuspended in fresh medium to an absorbance $\left(A_{578}\right)$ of between 0.05 and $0 \cdot 10$. This culture was incubated for $60 \mathrm{~min}$ (to allow two doublings) and then harvested by centrifugation. After one wash in cold $\left(4^{\circ} \mathrm{C}\right)$ iron uptake medium [IUM: $0.01 \mathrm{M}$-Tris $/ \mathrm{HCl}, \mathrm{pH} 7.2 ; 0.5 \%(\mathrm{w} / \mathrm{v})$ glucose; $1.0 \mathrm{mM}-\mathrm{MgSO}_{4} ; 100 \mu \mathrm{M}$-nitrilotriacetate] containing $50 \mu \mathrm{M}$-desferri-ferrichrome, bacteria were resuspended in cold IUM to an $A_{578}$ of 0.40 , corresponding to a dry weight of $0.38 \mathrm{mg} \mathrm{ml}^{-1}$. Following equilibration of $10 \mathrm{ml}$ suspension for $5 \mathrm{~min}$ at $37{ }^{\circ} \mathrm{C}$, a radioactive iron solution (Amersham Searle; $0.8 \mathrm{mCi} \mathrm{ml}^{-1}, 195 \mu \mathrm{g}$ $\mathrm{Fe}^{3+} \mathrm{ml}^{-1}$ ) was added as an equimolar complex of iron-ferrichrome to a final concentration of $1.0 \mu \mathrm{M}$. In experiments where cells were grown in minimal medium and then further in low-iron medium, they were washed three times in cold IUM, resuspended to an $A_{57}$ of 0.40 , and radioactive iron-ferrichrome was added as above. Samples of $1.0 \mathrm{ml}$ were removed at specified intervals; the bacteria were rapidly collected on filters (Schleicher \& Schüll, $0.45 \mu \mathrm{m}$ ), washed twice with $4 \mathrm{ml} 0.1 \mathrm{M}-\mathrm{LiCl}$, dried, and counted for radioactivity in a Nuclear Chicago Mark II liquid scintillation counter.

Separation of inner and outer membranes from $E$. coli. This was achieved by the method of Osborn et al. (1972). Bacteria were grown in TY medium to mid-exponential phase, converted to spheroplasts and lysed. Membranes were separated by sucrose density gradient centrifugation, such that the outer membrane fraction consisted of the heavy $(\mathrm{H})$ band harvested from the most dense region of the gradient.

Polyacrylamide gel electrophoresis. The method described by Lugtenberg et al. (1975) was used, with the modification that stock solution 1 contained $0 \cdot 3 \%(\mathrm{w} / \mathrm{v}) N, N^{\prime}$-methylenebisacrylamide.

Antibiotic sensitivity. This was determined by the method of Davis \& Mingioli (1950) using paper discs saturated with various concentrations of albomycin on plates containing $10 \mathrm{ml}$ minimal medium plus the dye 2,3,5-triphenyltetrazolium chloride. The diameter of the zone of inhibition was thereby clearly discernible.

Phage titration, selection of phage-resistant mutants and determination of colicin sensitivity. These procedures were described by Miller (1972). Phages T1 and T5 were from departmental stocks; strains resistant to T5 lacked the tonA-specified 78000 dalton outer membrane protein. Phages TuIa, TuIb and TuII* were provided by Ulf Henning as was phage TC45, isolated by John Foulds. The protein pattern of outer membranes from strains resistant to these latter phages is included in Table 1. Colicin M was prepared according to Braun et al. (1974).

\section{RESULTS}

\section{Mutants lacking major outer membrane proteins}

Mutants of Escherichia coli $\mathrm{K} 12$ with a highly altered outer membrane composition were selected by their resistance to phages which require 'major' proteins as their receptors. A $f e u B$ aro $B$ parent which cannot transport or produce enterochelin was chosen; the possible mechanisms for iron uptake would therefore be restricted to the ferrichrome, citrate, and low affinity systems. The phage resistance patterns are shown in Table 1 and the corresponding protein deficiencies in the outer membrane, as determined by sodium dodecyl 


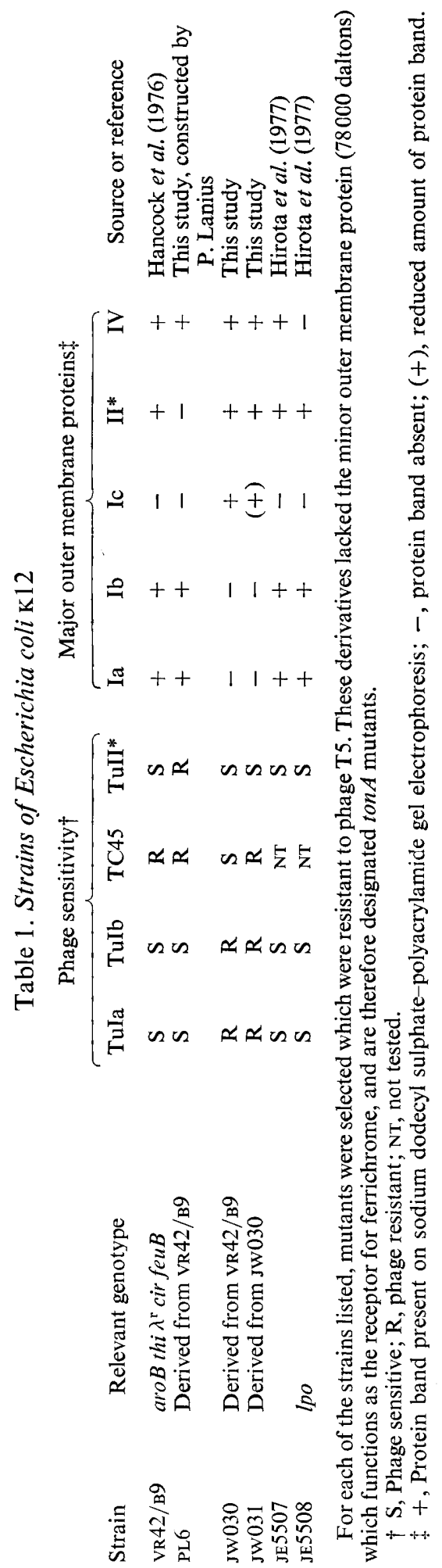




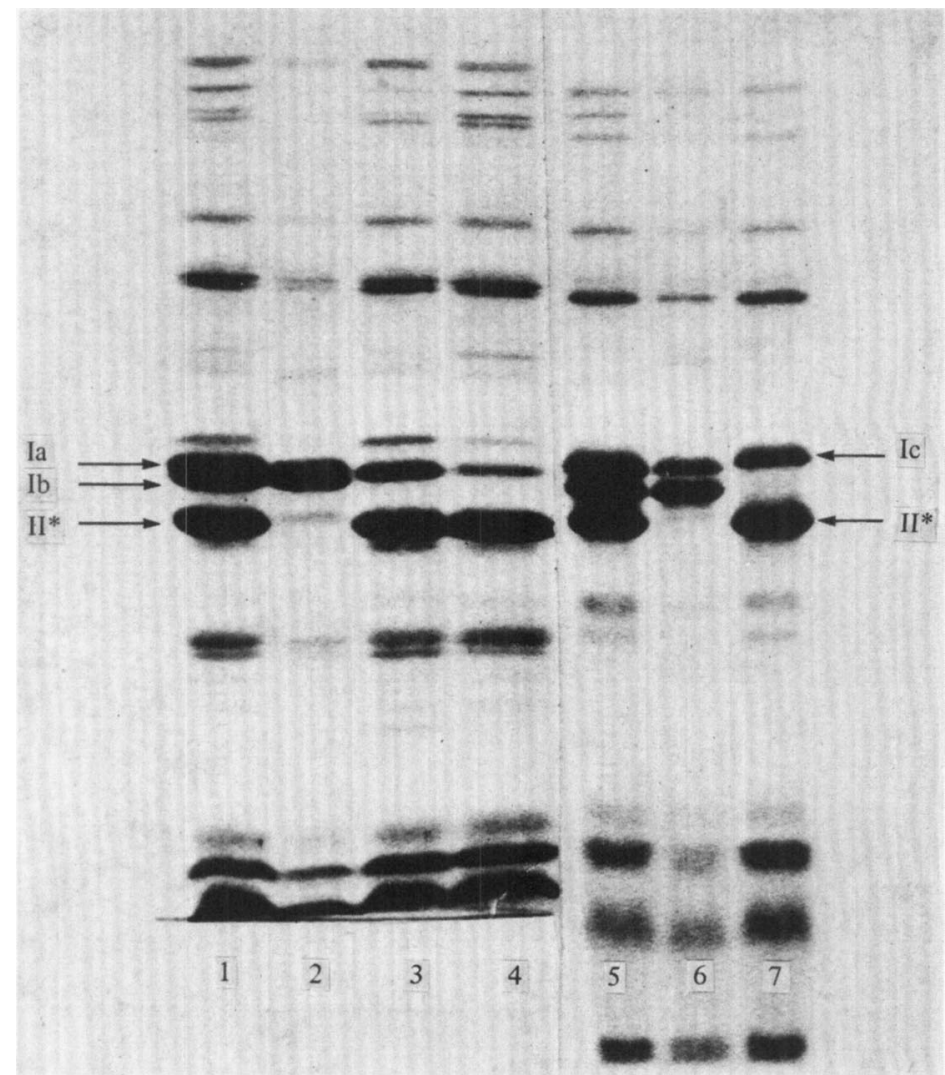

Fig. 1. A composite illustration of two separate runs of polyacrylamide slab gel electrophoresis of outer membrane proteins of $E$. coli $\mathrm{K} 12$ (the gel of wells 5 to 7 was run for a longer time than that of wells 1 to 4). Wells 1, 5: strain VR2/B9, 'wild type' for this study. Wells 2, 6: strain PL6, which lacks protein $\mathrm{II}^{*}$. Wells 3,7 : strain Jw030, which lacks proteins Ia and Ib but contains Ic (more clearly displayed in well 7). Well 4, strain Jw031, which contains diminished amounts of all I proteins.

sulphate-polyacrylamide gel electrophoresis, are shown in Fig. 1. Strain PL6 lacked protein II* and appeared not to be pleiotropic since it had not compensated for its deficiency by (over)producing other outer membrane proteins. Two steps of selection with phages Tula and TuIb gave rise to mutants totally lacking their respective protein receptors (e.g. strain Jw030). However, another protein, Ic, appeared (Henning et al., 1977). It was possible to reduce the amount of protein Ic by selection for resistance of Jw030 to phage TC45 that utilizes this protein as receptor (J. Foulds, personal communication). Such a strain (Jw031) was totally insensitive to all the three protein I-specific phages, and its gel electrophoresis pattern displayed an amount of protein I which was the lowest level achieved (Fig. 1).

Strain JE5508 of E. coli K12, which is completely deficient in protein IV (mureinlipoprotein), and its parent strain JE5507, which contains lipoprotein (Hirota et al., 1977), were also tested.

Mutants of all the strains listed in Table 1 were selected for resistance to phage T5. These derivatives lacked the ton $A$-specified gene product, i.e. the 78000 dalton outer membrane protein which acts as the receptor for ferrichrome.

\section{Uptake of ${ }^{55} \mathrm{Fe}$-ferrichrome into E. coli grown in rich medium}

High iron concentrations in TY medium suppress high affinity uptake systems for iron in E. coli. However, because the strains chosen have an aro $B$ feu $B$ background, the entero- 


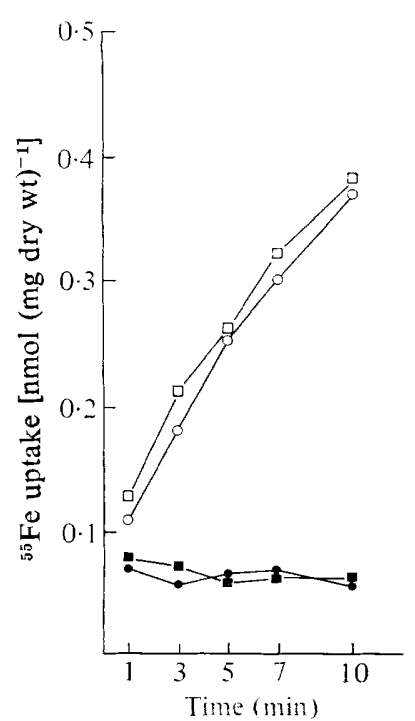

Fig. 2

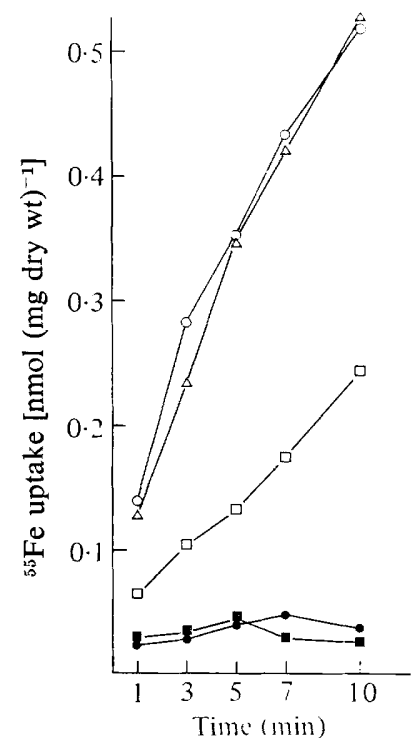

Fig. 3

Fig. 2. Ferrichrome-promoted ${ }^{55} \mathrm{Fe}$ uptake into strains of $E$. coli $\mathbf{k} 12$ grown in rich medium. Bacteria were washed in desferri-ferrichrome and then incubated with ${ }^{55} \mathrm{Fe}$-ferrichrome for $10 \mathrm{~min}: \bigcirc$, strain VR42/B9, which contains the full complement of outer membrane proteins; $\square$, strain PL6, which lacks protein $\mathrm{II}^{*}$. Results are also shown for the corresponding tonA strains lacking the outer membrane protein receptor for ferrichrome: $9, \mathrm{VR} 42 / \mathrm{B} 9$ tonA; $\mathbf{1}, \mathrm{PL} 6$ tonA.

Fig. 3. Ferrichrome-promoted ${ }^{55} \mathrm{Fe}$ uptake into strains of $E$. coli $\mathrm{k} 12$ grown under iron-starvation conditions. Bacteria were incubated with ${ }^{55} \mathrm{Fe}$-ferrichrome for $10 \mathrm{~min}: \bigcirc$, strain VR42/B9; $\square$, strain PL6; $\triangle$, strain Jw030, which lacks proteins Ia and Ib but contains Ic. The uptake curve (not shown) for strain Jw031 which contains diminished amounts of all the I proteins was superimposable on that for strain Jw030. Results are also shown for two tonA strains:, , VR42/B9 tonA; $\mathbf{\square}$, PI 6 ton $A$.

chelin-iron high affinity system was inoperative: enterochelin was neither synthesized nor transported. Citrate was not added to TY medium, so the citrate-iron uptake system was not induced. The low affinity iron uptake system would therefore satisfy the cells' requirements. It was, however, possible to test for iron uptake from the ferrichrome complex if bacteria were grown in TY medium, washed with desferri-ferrichrome, and presented with equimolar amounts of chelator and iron.

When the isogenic pair VR42/B9 ('wild type') and PL6 (II*-minus) were tested for ferrichrome-dependent iron uptake, the same initial velocity of iron incorporation and similar levels of iron uptake after a $10 \mathrm{~min}$ incubation period were observed (Fig. 2). Similarly, no marked differences were observed when the ferrichrome-promoted iron uptake into the protein I-deficient strains or into the lipoprotein-less mutant was compared with the uptake by their parents (data not shown). In all instances, ton $A$ derivatives showed a background level of ${ }^{55} \mathrm{Fe}$ uptake, probably representing non-specific adsorption.

\section{Uptake of ${ }^{55} \mathrm{Fe}$-ferrichrome into E. coli grown under iron stress conditions}

Iron stress was effected by transferring bacteria grown to early stationary phase in M9 medium containing sufficient iron into low-iron medium. All cultures continued to double with the same generation time for at least $4 \mathrm{~h}$ of iron starvation. A detailed comparison was made of strain VR42/B9 and its derivatives, PL6 (II*-minus), Jw030 (Ia-minus, Ib-minus, Ic-plus) and Jw031 (reduced levels of all I proteins); these four strains grew equally well. Whereas lack of proteins Ia, Ib and Ic did not seem to alter the uptake of iron-ferrichrome, 

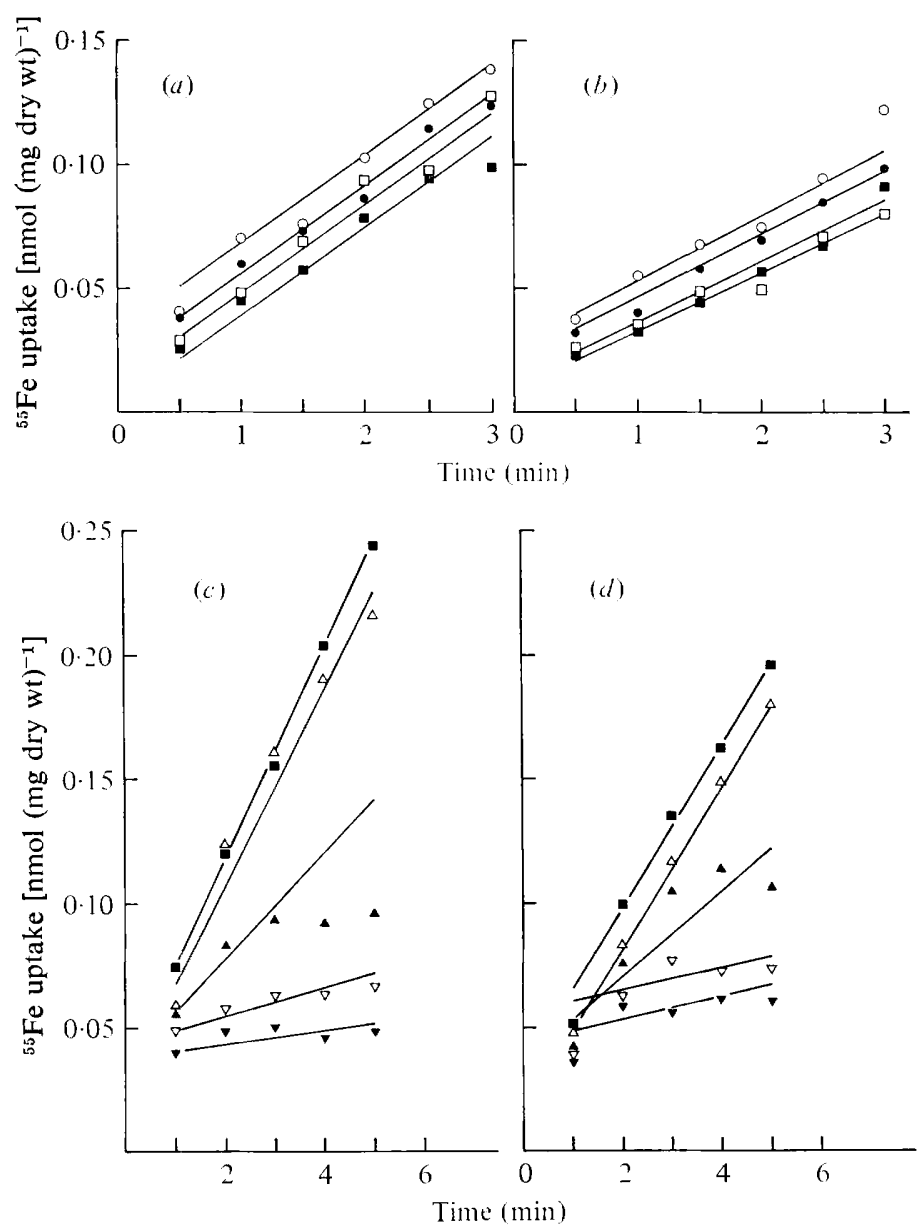

Fig. 4. Kinetics of transport of ${ }^{55} \mathrm{Fe}$-ferrichrome by strains of $E$. coli $\mathrm{K} 12$ grown under iron-starvation conditions for $4 \mathrm{~h}$ and then incubated with different concentrations of the iron-chelator complex. Uptake of radioactivity was followed for up to $5 \mathrm{~min}$. From these data, initial velocities of ferrichrome uptake could be determined. (a) Strain VR42/B9 and $(b)$ strain PL6, incubated with iron-ferrichrome at final concentrations $\left(\mu_{\mathrm{M}}\right)$ of: $\bigcirc, 1.0 ; 0,0.50 ; \square, 0.20 ; \mathbf{D}, 0 \cdot 10 .(c)$ Strain $V_{R} 42 / \mathrm{B} 9$ and $(d)$ strain PL6, incubated with iron-ferrichrome at final concentrations $(\mu \mathrm{M})$ of: $\boldsymbol{\nabla}, 0.100 ; \Delta, 0.050 ; \boldsymbol{\Delta}, 0.020$; $\nabla, 0 \cdot 013 ; \nabla, 0 \cdot 010$.

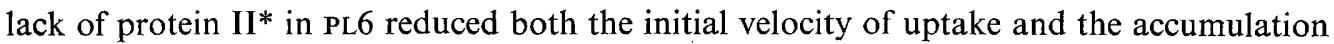
of iron in the $10 \mathrm{~min}$ observation period (Fig. 3). Again, ton A mutants of all strains showed a background level of ${ }^{55} \mathrm{Fe}$ incorporation from ferrichrome.

When the iron uptake of all strains grown in TY medium was compared with that of the strains grown in iron-depleted M9 medium, the rate of ferrichrome-promoted iron uptake and the total amount of iron incorporation were always greater for bacteria grown under iron stress conditions.

\section{Kinetics of uptake of ${ }^{55} \mathrm{Fe}$ from ferrichrome}

To explore and characterize the basis for diminished ferrichrome-promoted iron uptake into the protein $\mathrm{II}^{*}$-deficient strain, detailed kinetic studies of ferrichrome-iron incorporation were carried out on strains VR42/B9 and PL6. The ratio of iron to ferrichrome was always maintained at $1: 1$, and concentrations from 1.0 to $0.01 \mu \mathrm{M}$ were used in the assay.

Iron stress was imposed such that the bacteria were grown for at least four generations in low-iron medium. For both the wild type and the protein $I^{*}$-deficient mutant, a family of 


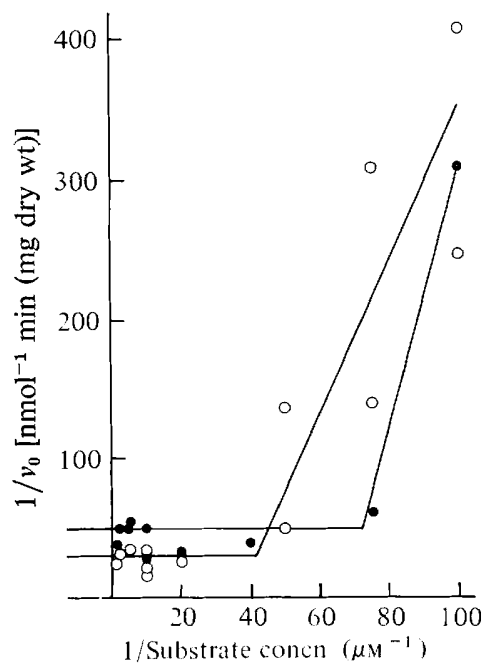

Fig. 5. Double reciprocal plots of velocity of uptake of ${ }^{55} \mathrm{Fe}$-ferrichrome versus substrate concentration for $E$. coli $\mathrm{K} 12$ strain VR42/B9: $\bigcirc$, grown in iron-extracted M9 medium; 9 , grown in M9 medium plus $10 \mu \mathrm{M}-\mathrm{FeCl}_{3}$. Initial velocities were calculated from several sets of data comparable to those shown in Fig. $4(a, c)$.

lines was generated showing uptake of ${ }^{55} \mathrm{Fe}$ from ferrichrome as a function of time up to $5 \mathrm{~min}$. From such information, a rate could be calculated. From $1 \cdot 0$ to $0 \cdot 1 \mu \mathrm{M}$, these lines were parallel (Fig. $4 a, b)$; the maximum rates were 0.030 and $0.023 \mathrm{nmol} \mathrm{min}^{-1}\left(\mathrm{mg}\right.$ dry wt) ${ }^{-1}$ for $\mathrm{VR} 42 / \mathrm{B} 9$ and $\mathrm{PL} 6$, respectively. Lower concentrations of iron-ferrichrome $(0 \cdot 10$ to $0.01 \mu \mathrm{M})$ led to rate-limiting incorporation, as shown by the decreasing slopes of the lines in Fig. $4(c, d)$. Replots of this data as reciprocal velocity versus reciprocal concentration showed an unusual pattern: instead of straight lines intersecting the negative abscissa, the lines were parallel to the abscissa at high concentrations of iron-ferrichrome, and then showed a marked discontinuity at low substrate concentrations (Fig. 5). It was therefore not possible to determine a value for the $K_{\mathrm{m}}$ of ferrichrome due to the biphasic nature of the curves.

Iron sufficient conditions were provided by adding $10 \mu \mathrm{M}-\mathrm{FeCl}_{3}$ to $\mathrm{M} 9$ salts. As in ferrichrome-promoted iron uptake into bacteria grown in low-iron medium, kinetic data showed a family of lines for $v_{0}$ versus [S] which were parallel in the range of concentrations from 1.0 to $0.1 \mu \mathrm{M}$ for both strains. Noticeable, however, was a considerably diminished maximum velocity in each case: 0.020 and $0.015 \mathrm{nmol} \mathrm{min}^{-1}\left(\mathrm{mg}\right.$ dry wt) ${ }^{-1}$ for VR42/B9 and PL6, respectively. When substrate concentrations were lowered to between 0.10 and $0.01 \mu \mathrm{M}$, the velocity of ${ }^{55} \mathrm{Fe}$ incorporation was again rate-limiting. The double reciprocal plot was biphasic as before, such that a $K_{\mathrm{m}}$ for iron-ferrichrome could not be determined.

\section{Other tonA-dependent properties}

Under certain conditions, protein $\mathrm{II}^{*}$ could thus be shown to be necessary for tonAdependent ferrichrome uptake. Other ton $A$-dependent functions were then tested in the outer membrane mutants which were grown to mid-exponential phase in unextracted M9 medium. Since the tests necessitated a discernible lawn of bacteria on agar plates after overnight incubation, the sensitivities could not be determined in low-iron medium due to insufficient growth. Tests for albomycin sensitivity revealed no major differences between the mutants and the parent. In tests for colicin $M$ receptor activity, all the mutants severely altered in outer membrane protein composition but still retaining tonA protein showed clearing by the same titre of colicin $\mathrm{M}$. The plating efficiencies of phages $\mathrm{T} 1$ and $\mathrm{T} 5$ on VR42/B9, PL6 and JW030 were identical. 


\section{DISCUSSION}

Although it is well known that the tonA gene product in the outer membrane acts as receptor for the iron-ferrichrome complex, it is of considerable interest whether any reorganization of the membrane might affect the receptor properties of the tonA protein. By studying ferrichrome-promoted iron uptake in mutants lacking major outer membrane proteins, it was possible to exclude effects of proteins I and of lipoprotein upon tonA activity. The uptake of ${ }^{55} \mathrm{Fe}$ from ferrichrome was virtually identical in the strains with reduced amounts of protein I, in the lpo mutant and in the wild-type strain. The result for the lipoprotein-less mutant concurs with recently published information on the permeability of the outer membrane to 6-aminopenicillanic acid (Nikaido et al., 1977). The diffusion rate of this $\beta$-lactam antibiotic was similar in $l p o$ and $l p o^{+}$strains, suggesting that lipoprotein by itself does not form non-specific pores for hydrophilic molecules. In the absence of ton $A$ protein in the Ipo mutant, there is only background uptake of ${ }^{55} \mathrm{Fe}$ representing non-specific adsorption. Clearly, lipoprotein cannot act as an alternative channel for ferrichrome through the outer membrane, nor does it appear to influence the ferrichrome-iron uptake system.

The maximum velocity of uptake of iron is displayed by strains which possess a full complement of outer membrane proteins and which are grown under iron deficiency. The rate of ferrichrome-uptake is lowered if the cells are grown with a supplement of $10 \mu \mathrm{M}$ $\mathrm{FeCl}_{3}$; with such elevated iron concentrations it is likely that the low affinity system is operative and sufficient to provide for the cells' requirements. In these instances, the velocity of ${ }^{55} \mathrm{Fe}$ incorporation fell from 0.030 to $0.020 \mathrm{nmol}$ iron $\mathrm{min}^{-1}$ (mg dry wt) ${ }^{-1}$. Such data further support the concept that it is the intracellular supply of iron which regulates the amount of iron proteins in the outer membrane as well as their activity (Braun et al., 1976; McIntosh \& Earhart, 1977).

The most pronounced effect on the kinetics of ferrichrome-iron uptake was that exerted by protein II*. When initial velocities were calculated for iron uptake by strains VR $42 / \mathrm{B} 9$ and PL6, a $40 \%$ decrease was observed for the protein II*-deficient strain. This relative difference was maintained even when a plentiful supply of iron was provided in the minimal M9 medium, but was abolished if cells were grown in rich medium. The amounts of protein II*, as estimated by polyacrylamide gel electrophoresis, did not fluctuate markedly if bacteria were grown in TY or in M9 medium; there were, however, differences in the amounts of 'minor' proteins when bacteria were grown in different media. It is also noteworthy that these kinetic phenomena were not attributable to general metabolic defects, since the doubling times for the strains were identical. In contrast to the results of Manning et al. (1977), no defect in amino acid uptake was detected (unpublished observations).

The peculiar nature of the biphasic curves of the double reciprocal plots of velocity versus substrate concentration probably reflects the multi-component nature of the ferrichromeiron uptake system. If binding of ferrichrome to the outer membrane were rate-limiting by the low availability of functional binding sites, then no increase in the concentration of the substrate would enhance the velocity of the first step in uptake by this membrane. Preliminary evidence indicates that the $E$. coli outer membrane is endowed with such a low number of specific receptors that this interpretation would be allowable.

The idea that protein II* itself forms pores for the passage of ferrichrome is untenable, according to the data shown in Fig. 3. The uptake curves for tonA-derivatives of strains with or without protein II* demonstrate the same background levels of iron after 10 min incubation with ferrichrome. If protein II* were to act as an alternative channel for the chelator-iron complex, then uptake by the protein $\mathrm{II}^{*}$-containing strain would be significantly higher. Uptake of ferrichrome-iron seems to be strictly dependent upon the presence of the receptor protein specified by the ton $A$ gene, and no bypass system has yet been detected for this requirement.

Protein $\mathrm{II}^{*}$ may either influence the proper functioning of the presumptive tonA protein 
pore or it may act on a subsequent step of the ferrichrome translocation process. In accordance with the known biochemical differences in membranes of cells grown in various media it is conceivable that protein $\mathrm{II}^{*}$ exerts its effect by giving rise to different interactions of membrane components.

It has not yet been established whether loss of protein II* results in a specific or a general defect in outer membrane transport systems. Citrate-iron transport is highly diminished in protein $\mathrm{II}^{*}$-deficient strains, whereas dihydroxybenzoate-promoted iron uptake is unaffected by loss of protein $\mathrm{II}^{*}$ (unpublished observations). These data would support the idea that some outer membrane high-affinity uptake systems are dependent for their activity upon this major protein.

Variations in the composition of outer membrane proteins in response to lipopolysaccharide mutations (Ames et al., 1974) and in response to medium and to osmolarity (Van Alphen \& Lugtenberg, 1977) are now well documented. The significance of these fluctuations in terms of functional characteristics, however, is less clear. The data in this paper relate one instance where a function of an outer membrane protein is influenced by the medium in which the bacteria are grown and by the composition of the outer membrane itself: growth in rich medium diminished the initial velocities of uptake of ferrichrome-iron as compared to growth in M9 salts; the presence of protein $\mathrm{II}^{*}$ influenced a high affinity receptor system attributable to a minor protein.

The excellent technical assistance of Helga Wolff is much appreciated. We thank Ulf Henning for providing phages including phage TC45 isolated by John Foulds, National Institutes of Health, Bethesda, U.S.A. Research was conducted with the financial support of the Deutsche Forschungsgemeinschaft (Sonderforschungsbereich 76). J.W.C. is a Fellow of the Medical Research Council of Canada, and of the Alexander von Humboldt Stiftung, Bonn, West Germany.

\section{REFERENCES}

ADAMS, M. H. (1959). Bacteriophages. New York: Interscience.

Ames, G. F., Spudich, E. N. \& Nikaido, H. (1974). Protein composition of the outer membrane of Salmonella typhimurium: effect of lipopolysaccharide mutations. Journal of Bacteriology 117, 406-416.

BRAUN, V. \& HANTKE, K. (1977). Bacterial receptors for phages and colicins as constituents of specific transport systems. In Microbial Interactions (Receptors and Recognition, series B, vol. 3), pp. 100-137. Edited by J. L. Reissig. London: Chapman and Hall.

Braun, V., Schaller, K. \& Wabl, M. R. (1974). Isolation, characterization and action of colicin M. Antimicrobial Agents and Chemotherapy 5, $520-533$.

Braun, V., Hancock, R. E. W., Hantke, K. \& HartmanN, A. (1976). Functional organization of the outer membrane of Escherichia coli: phage and colicin receptors as components of iron uptake systems. Journal of Supramolecular Structure 5, 37-58.

Davis, B. D. \& Mingioli, E. S. (1950). Mutants of Escherichia coli requiring methionine or vitamin B12. Journal of Bacteriology 60, 17-28.

Haller, I. \& Henning, U. (1974). Cell envelope and shape of Escherichia coli $\mathrm{K} 12$. Crosslinking with dimethyl imidoesters of the whole cell wall. Proceedings of the National Academy of Sciences of the United States of America 71, 20182021.

Hancock, R. E. W., Hantke, K. \& Braun, V. (1976). Iron transport in Escherichia coli K12: the involvement of the colicin $B$ receptor and of a citrate-inducible protein. Journal of Bacteriology 127, 1370-1375.

HantKe, K. \& Braun, V. (1975a). Membrane receptor dependent iron transport in Escherichia coli. FEBS Letters 49, 301-305.

HANTKe, K. \& BraUn, V. (1975 b). A function common to iron-enterochelin transport and action of colicins B, I, V in Escherichia coli. FEBS Letters 59, 277-281.

Henning, U., Schmidmayer, W. \& Hindennach, I. (1977). Major proteins of the outer cell envelope membrane of Escherichia coli $\mathrm{K} 12$ : multiple species of protein I. Molecular and General Genetics 154, 293-298.

Hirota, Y., Suzuki, H., Nishimura, Y. \& Yosuda, S. (1977). On the process of cellular division in Escherichia coli: a mutant of Escherichia coli lacking a murein-lipoprotein. Proceedings of the National Academy of Sciences of the United States of America 74, 1417-1420.

Luckey, M., Wayne, R. \& Neilands, J. B. (1975). In vitro competition between ferrichrome and phage for the outer membrane T5 receptor complex of Escherichia coli. Biochemical and Biophysical Research Communications 64, 687-693. 
Lugtenberg, B., Meijers, J., Peters, R., Van der HoEk, P. \& VAN Alphen, L. (1975). Electrophoretic resolution of the "major outer membrane protein' of Escherichia coli $\mathrm{K} 12$ into four bands. FEBS Letters 58, 254-258.

Manning, P. A., Pugsley, A. P. \& Reeves, P. (1977). Defective growth functions in mutants of Escherichia coli $\mathrm{K} 12$ lacking a major outer membrane protein. Journal of Molecular Biology 116, 285-300.

McIntosh, M. A. \& Earhart, C. F. (1977). Coordinate regulation by iron of the synthesis of phenolate compounds and three outer membrane proteins in Escherichia coli. Journal of Bacteriology 131, 331-339.

Miller, J. H. (1972). Experiments in Molecular Genetics. Cold Spring Harbor, New York: Cold Spring Harbor Laboratory.

NAKAE, T. \& Nikaido, H. (1975). Outer membrane as diffusion barrier in Salmonella typhimurium. Penetration of oligo- and polysaccharides into isolated outer membrane vesicles and cells with degraded peptidoglycan layer. Journal of Biological Chemistry 250, 7359-7365.

Nikaido, H., Bavoll, P. \& Hirota, Y. (1977). Outer membranes of Gram-negative bacteria. XV. Transmembrane diffusion rates in lipoproteindeficient mutants of Escherichia coli. Journal of Bacteriology 132, 1045-1047.
Osborn, M. J., Gander, J. E., Parisi, E. \& Carson, J. (1972). Mechanism of assembly of the outer membrane of Salmonella typhimurium. lsolation and characterization of cytoplasmic and outer membrane. Journal of Biological Chemistry 247, 3962-3972.

Palva, E. T. \& Randall, L. L. (1978). Arrangement of protein I in Escherichia coli outer membrane: cross-linking study. Journal of Bacteriology 133, 279-286.

Reithmeier, R. A. F. \& BragG, P. D. (1977). Crosslinking of the proteins in the outer membrane of Escherichia coli. Biochimica et biophysica acta 466, 245-256.

Schweizer, M. \& Henning, U. (1977). Action of a major outer cell envelope membrane protein in conjugation of Escherichia coli K12. Journal of Bacteriology 129, 1651-1652.

Schweizer, M., Hindennach, I., Garten, W. \& HenNing, U. (1978). Major proteins of the Escherichia coli outer cell envelope membrane. Interaction of protein II* with lipopolysaccharide. European Journal of Biochemistry 82, 211-217.

VAN Alphen, W. \& LugtenberG, B. (1977). Influence of osmolarity of the growth medium on the outer membrane protein pattern of Escherichia coli. Journal of Bacteriology 131, 623-630. 